\title{
Cooperation and Its Role in Facilitation of Foreign Expansion: Example of Slovak Enterprises ${ }^{1}$
}

\author{
Mária Šášiková, Tatiana Hlušková
}

\begin{abstract}
A B S T R A C T
Objective: The objective of the paper is to point out the importance of cooperation between companies in order to facilitate their internationalization, based on the example of Slovak-foreign joint ventures and to present institutions supporting these partnerships.
\end{abstract}

Research Design \& Methods: We posit that foreign expansion is an important motive for the cooperation of the enterprises. This hypothesis is tested on the sample of 44 Slovak-foreign joint ventures, which participated in the questionnaire survey. Furthermore, we aim to present various options supporting the cooperation of companies in Slovakia, based on own experience and knowledge gained during the work for Enterprise Europe Network (EEN).

Findings: According to the survey, the majority of companies are satisfied with joint venture performance and plan to continue their cooperation. Motives linked to the foreign expansion are among the most important for the joint venture establishment.

Implications \& Recommendations: The awareness of institutions' tools supporting partnerships is rather limited among Slovak companies.

Contribution \& Value Added: Research about establishment motives and satisfaction with the joint venture performance has not been conducted yet in Slovakia.

\begin{tabular}{ll}
\hline Article type: & research paper \\
Keywords: & co-operation; Central Europe; internationalization; joint venture \\
JEL codes: & F23, F55, L24
\end{tabular}

Published by Centre for Strategic and International Entrepreneurship - Krakow, Poland

\section{Suggested citation:}

Šášiková, M., \& Hlušková, T. (2013). Cooperation and Its Role in Facilitation of Foreign Expansion: Example of Slovak Enterprises. Entrepreneurial Business and Economics Review, 1(4), 83-96.

\footnotetext{
${ }^{1}$ The article came into being within the project VEGA no. $1 / 1185 / 12$ and the project VEGA no. 1/0461/12.

${ }^{2}$ The contribution of co-authors is equal and can be expressed as $50 \%$ each of the authors.
} 


\section{INTRODUCTION}

The aim of the paper is to point out the importance of cooperation as a means of facilitation of companies' foreign expansion, based on the example of Slovak firms. The research was conducted on the sample of 44 Slovak-foreign joint ventures, which participated on the questionnaire survey concerning planning, managing and performance outcomes of international joint ventures with the participation of Slovak companies.

Slovak economy is heavily dependent on exports, however, many of the biggest exporting companies can be counted among the wholly-owned affiliates of foreign companies. One of the pressing problems of Slovakia is the rather low share of local - notably the small and medium-sized enterprises (SMEs) in the overall value of exports. As these types of companies often had to cope with the lack of resources needed for successful expansion abroad, the cooperation with foreign firms might be a suitable solution facilitating their internationalization. There are several types of these partnerships, but joint venture is the one with the highest resource commitment of the respective partners. Based on the example of Slovak-foreign joint ventures, the paper aims to point out the importance of cooperation between companies in order to facilitate their internationalization. Findings include presentation of means and possibilities of launching cooperation with potential business partners provided by Slovak and European institutions.

\section{LITERATURE REVIEW}

\section{Internationalization and the Role of Cooperation between Companies as Its Facilitator}

In the CEE (Central and Eastern European) countries the tradition of entrepreneurship was interrupted by the era of the socialist regimes. This fact, along with the less entrepreneurship-friendly business environment in some of the countries, poses significant threats for the successful foreign expansion of CEE companies.

According to Johanson and Vahlne (cited in Nowiński \& Rialp, 2013), companies with more abundant resources may skip the earlier stages and speed up their internationalization. As for the SMEs, which have to cope with the resource scarcity, there might be two solutions of this problem: to acquire external resources or to substitute some resources with others, which are available for the company at the moment. Both of these possibilities could be closely tied to strategic alliances. Acquisition of external resources might take the form of cost-sharing or sharing of the distribution channels on the foreign markets with other companies. As for the substitution of resources, financial resources needed for the foreign market research might be replaced with the knowledge of the partner firm, which is already active in the given market.

There are many different definitions of strategic alliances, but all of them agree upon the basic point: strategic alliances are partnerships of two or more entities in order to achieve specific strategic goals, notably to gain competitive advantage. Strategic alliances enable the companies involved to make use of the opportunities which would otherwise be beyond the capabilities of a single firm (Ferenčíková et al., 2013). For these 
reasons strategic partnerships could play an important role in enabling or facilitating the internationalization processes of companies, especially SMEs. SMEs encounter even more challenges, as they often need to cope with the resource (notably financial) constraints. Other important issue is the absence of previous experience with the foreign markets. In the case of former socialist countries in the Central and Eastern Europe, negative country-of-origin effect could also pose a threat to successful internationalization.

Strategic alliances can be divided into two types. Contractual agreements can be formed along the whole value chain. Thus, the partners in contractual alliances combine their resources only in a certain field of business activity. Equity arrangements can take form of joint ventures, minority equity alliances or equity swaps (Ferenčíková et al., 2013). As for the internationalization of SMEs, the most important motives may be the foreign market entry itself (e.g., via foreign partner distribution channels), lowering the costs of internationalization and learning from the partner in terms of the foreign market knowledge.

Joint ventures played an important role in transformation of Slovak economy after the fall of the socialist regime in 1989. Slovakia opened its market for the foreign investors in the beginning of 1990s under the condition that the foreign companies would create a joint venture with local firms (mostly the state-owned enterprises designated for privatization). Nevertheless, the expectations of Slovak companies entering joint ventures in 1990 s were mostly unmet. They entered the partnerships with the aim to learn from the partner, to enter its distribution channels in the foreign markets and to transfer the knowledge, technology and know-how of the foreign investors. From the beginning, the intentions of some foreign companies were completely different - often aimed at full acquisition of the Slovak firms, with little or no willingness to share the most valuable assets with them. Even if the Slovak company itself had not ceased to exist, it usually withdrew from the joint venture, which eventually became a fully-owned subsidiary of the foreign company (Ferenčíková, 2001).

Based on the case studies of six Slovak-foreign joint ventures created in 1990s, S. Ferenčíková (2001) pointed out the positive effects the foreign investors had on the companies involved:

- Change in product line towards high-quality product: either totally or partially at first - beginning with modifications of local partner's products and only later introducing new products and models.

- Technology improvement: by the means of the technology transfer or by the facilitation of the technology acquisition; in the six cases investigated, none of the foreign investors contributed obsolete technology.

- Higher quality of labour force: even though the labour force in Slovak companies was relatively highly skilled, foreign investors provided training on new technologies, work practices or foreign languages. The quality of local employees was so high that the need to bring expatriates to the joint ventures was on the minimal level.

- Implementation of management know-how: all of the foreign companies brought new methods of human resources management and also adjusted the organizational structures to the needs of the market economy. The joint ventures also underwent major changes in the fields of accounting and finance. 
- Implementation of modern marketing practices: they mainly concerned the market research application and specific methods of high-quality products marketing. All these changes resulted in customers' satisfaction improvement. The adjustments were also made in the value chain, which internationalized in two ways: the joint ventures entered the supply network of the foreign investor and were also able to increase their exports.

- Foreign market know-how: most of the joint ventures (all of which were export-oriented) learned how to conduct the business in the foreign markets themselves. However, some of the transactions abroad were still managed by the foreign partners.

- Increase of productivity: reflects better organization of labour and new management practices, higher quality of labour force, new technologies and more intensive production.

The partnerships with foreign investors had a limited impact on the Slovak parent companies, with the "unintentional learning" being the most important. Spreading of managerial attitudes, ethics, corporate culture and work practices were observed in all of the six cases. However, according to S. Ferenčíková (2001) change within the local company depended to a much greater extent on the attitude of its management than on the operations of the foreign partner.

A solution to the possible negative country-of-origin effect may be provided by a joint marketing alliance, which is combining companies' marketing activities in a certain market. A key feature of joint marketing alliances is that partner firms usually combine their marketing efforts by offering a unified image in the given marketplace (Teng \& Das, 2008). Cooperation could be used as a shortcut to knowledge acquisition which the partners would not be able to create within an acceptable time or at acceptable costs themselves, e.g., the knowledge about foreign markets, distribution channels or consumers (Das \& Teng, 2000).

As for the internationalization of the companies, the concept of International New Ventures (INVs) may be useful in explaining the foreign expansion of SMEs from Slovakia, as shows the example of Slovak technology companies such as ESET (security software), Sygic (navigation software) or aSc (scheduling software for schools). Each of these companies achieved worldwide success and each of them entered the markets abroad soon after their inception.

The International New Venture theory explains how companies with limited resources can achieve success at the international level. International New Venture, according to Oviatt and McDougall (1994) is "a business organization that, from the inception, seeks to derive significant competitive advantage from the use of resources and the sale of outputs in the multiple countries". In short, international new venture can be described as an organisation that is international from its inception. INVs bypass earlier stages of internationalization and use higher entry modes when going abroad.

As for the studies concerning INVs from transition economies - let alone CEE countries - there are only a few, as the interest of researchers is focused mainly on highly developed economies (e.g., USA, Canada or Western European countries). Nevertheless, based on the previous research, findings about internationalization of a firm from Western economies may not be fully applicable to emerging or transition 
economies. The reasons could be institutional differences or resource (both tangible and intangible, such as international business experience) constraints observable in these two types of economies (Nowiński \& Rialp, 2013).

In their study of four Polish International New Ventures, Nowiński and Rialp (2013) state that while these companies benefited from the developments of Poland's EU accession, these circumstances did not solely determine their early internationalization. Rather new information and communication technologies contributed to the successful foreign expansion, as they lowered the barriers of foreign market entry.

Internationalization of high-tech companies is often based on their unique resources, which form the basis of the company's competitive advantage. The examples of Slovak INVs aSc, ESET and Sygic illustrate that human resources are the most important, because people are the authors of the technology and innovation needed to achieve success at the international level. As the markets and the technology itself is a subject of constant change, the competitive advantage is at the threat of lagging behind the development of markets and customers' needs.

According to A. Osarenkhoe (2008), who conducted a study of 60 Swedish SMEs operating abroad and foreign SMEs operating in Sweden, sequential internationalization models cannot describe the foreign expansion of companies in general. All the companies willing to expand abroad have to bank on certain transaction costs of internationalization, which increase its riskiness. Nevertheless, there are certain factors which enable non-sequential foreign expansion, which is especially important for the companies from the developing and emerging countries. These factors include:

- Changed environmental conditions following globalization: diminishing differences between economies, which in turn lowers the risks tied to foreign expansion. As the world economy is becoming more and more homogenous, the costs and risks of internationalization decrease.

- The role of technology in the internationalization process: the information and communication technologies (ICT) lower the internationalization costs, which is especially important for the often resource-constrained SMEs. ICT facilitate the contact of potential customers abroad, as well as gaining the information about the foreign markets.

- Business-specific factors: they are the characteristics or nature of the product being sold. The globalization and emergence of new technologies led to the increased specialization of the companies. They tend to choose the niche market segments, where they can achieve success with their innovative and high-quality product without the need to face the keen competition.

- Entrepreneurial prowess: the managers in INVs often have previous experience with foreign markets (which also means a possibility they have already created a network abroad) and are less risk-averse than managers in other companies. They tend not to differ between the domestic and foreign markets.

- International networking and relationship conceptualization: networks provide an important possibility of learning from the partners, to gain access to their resources and to share risks. All these three aspects are vital especially for the SMEs willing to expand abroad. 
The export success of Slovakia is based mainly on large companies, namely in the automotive and consumer electronics sectors. The biggest exporters are the foreign-owned subsidiaries, such as Volkswagen, Kia, PSA Peugeot Citroën, Samsung or Slovnaft. Nevertheless, SMEs are lagging behind the large companies in terms of export performance. Increase of SMEs' share of overall exports is one of the goals of Slovakia's pro-export strategy for the period of 2014- 2020 (Ministry of Economy of the Slovak Republic, 2013). In 2012, the number of exporting SMEs reached 27 474, which stands for $97.1 \%$ of all Slovak exporters. However, the value of SME exports was 17486 billion EUR, which represents only $27.8 \%$ of the overall value of Slovak exports. This disproportion needs to be addressed, according to the state institutions.

\section{MATERIAL AND METHODS}

The goal of the paper is to point out the importance of cooperation as a means of facilitation of companies' foreign expansion, based on the example of Slovak firms. We posit that foreign expansion is an important motive for the cooperation of the enterprises. This hypothesis is tested on the sample of 44 Slovak-foreign joint ventures, which participated in the questionnaire survey concerning planning, managing and performance outcomes of international joint ventures with the participation of Slovak companies. The firms were included in the survey only if they met one of these conditions:

- the company is a partner in an international joint venture established and conducting business in Slovakia,

- the company established in Slovakia is a partner in international joint venture established and conducting business in country other than Slovakia.

The names of potential joint ventures with Slovak participation or joint venture partners were searched for in the newspapers, magazines and on the Internet, as there is no central or partial evidence of these entities in Slovakia. These companies were contacted by phone, with the aim to establish a connection with someone authorized to provide information on the cooperation with the foreign partner. Subsequently, he/she was sent an e-mail with the questionnaire attached. Some of the companies included in the research were asked to participate based on the previous knowledge of the authors about their equity structure.

The questionnaire consisted of questions referring to the importance of various motives for the joint venture creation. A five point scale was applied as follows: 1 - not important at all, 2 - minor importance, 3 - some importance, 4 - rather strong importance, 5 - very important. The respondents were also inquired about their satisfaction with the overall performance of the joint venture with a five point scale: 1 - very dissatisfied, 2 - dissatisfied, 3 - neutral, 4 - satisfied, 5 - very satisfied.

Additional to survey research, the intent was to present various options supporting the cooperation of companies in Slovakia. Own experience and knowledge gained during the work for EEN were used while writing the paper alongside documents and secondary data provided by EEN. 


\section{RESULTS AND DISCUSSION}

\section{Results of the Slovak-foreign Joint Ventures' Survey}

Even though the international joint ventures played an important role in the beginning of the Slovak economy's transition, no detailed research of these entities was conducted to this day, except of several studies based only on very limited number of companies in 1990s. Results of the following research thus provide the first more detailed information about these companies.

The research sample of the Slovak-foreign joint ventures consists of 17 (38.64\%) large (250 and more employees), 7 (15.91\%) medium-sized (50 - 249 employees), $10(22.73 \%)$ small (10 - 49 employees) and 8 (18.18\%) micro-enterprises (less than 10 employees). Two companies stated their number of employees only in the interval of 10 - 99, we can therefore assume they are either small or medium-sized firms. This division is based on the European Commission definition of the small and medium-sized enterprises (European Commission, 2003).

$16(36.36 \%)$ companies are active in the field of industrial products, $4(9.09 \%)$ in the field of consumer products, $3(6.82 \%)$ firms in the both of them. The line of business of the remaining companies can be labelled as "other" - meaning mostly various types of services, but also agriculture or technology development.

The results of the research suggest that the most important motives for partners in international joint ventures with Slovak participation are establishment of a base to access other countries' markets (average response value 3.25), gaining access to new technologies (average response value is 3.11) and gaining access to the distribution channels of the partner (average response value is 3.07). Two of these three motives could be directly linked to the Slovak companies' willingness to expand their business abroad: establishment of a base to access foreign markets and gaining access to the distribution channels of the partner.

On the other end of the spectrum, the need to overcome regulation barriers of local government (average response value 2.11) and access to the low-cost resources (average response value 2.41) are the least important reasons to create partnership with foreign company, according to the respondents' opinion. The lower need of low-cost resources might be explained by the fact that Slovak companies themselves dispose of resources relatively cheaper than those of the investor, notably the labour force. Another reason might be the lower resource-intensity of the business activities (e.g., in the sector of services).

Only minor importance of overcoming government regulation barriers might be interpreted by the structure of joint venture partners: majority of them comes from the EU member states and all the joint ventures included in the research are established in EU countries as well.

Compared to the results of previous study by S. Ferenčíková (2001), the emancipation of Slovak entrepreneurs willing to cooperate with foreign partners (in order to become more competitive in the home market or even to enter foreign markets) is visible. This development was encouraged by the period of rapid export-oriented economic growth of the Slovak economy. Moreover, many Slovak 
companies started to seek for partnership opportunities abroad as well, resulting in the foreign direct investment of Slovak companies in the form of international joint ventures.

The joint venture partners were also asked about the share of exports on the joint venture sales. Of the 44 companies inquired, 8 did not answer the question concerning the share of the joint venture sales assigned to exports and 12 firms stated the share is in the $0-4 \%$ range. However, 8 of these 12 companies have only limited exporting possibilities, as they are active in the fields as waste management, utilities and services. Share of exports on the overall sales higher than $50 \%$ can be observed in 12 cases, another 12 joint ventures have this percentage in $5-49$ range. More than half of the joint ventures are thus active in exporting, at least to limited extent. However, it cannot be ruled out that some of the other companies would not expand their activities abroad in the future.

Even though only $8(19.05 \%)$ companies are very satisfied with the overall performance, as many as $23(54.76 \%)$ firms are satisfied and only $2(4.76 \%)$ are dissatisfied. $9(21.43 \%)$ companies hold the neutral view. The average response value is 3.88. 42 companies expressed their opinion on overall joint venture performance.

In general, the benefits of participating in a joint venture with foreign company are obvious. The partnerships could be very helpful especially in the case of companies lacking the resources such as foreign market knowledge or access to distribution channels abroad. The survey results show that the partners are satisfied with their performance and as many as 36 companies at least partly agreed with the claim that they plan to continue their participation in the international joint venture in the long-term horizon.

\section{Institutions and Tools Facilitating the Creation of Partnerships between the Companies}

\section{SARIO}

Slovak Investment and Trade Development Agency (SARIO) is an institution which provides support for foreign enterprises willing to invest in Slovakia, but also for Slovak companies which aim to enter foreign markets and they are looking for the partnership opportunities. SARIO facilitates the cooperation with foreign entities by several means:

- the Slovak Sourcing and Cooperation Portal, the automatic matchmaking portal aimed to coordinate foreign firms' demands with production possibilities of the Slovak companies,

- organization of business journeys and fairs with the possibility of negotiations with prospective partners,

- organization of matchmaking events in Slovakia - e.g. Slovak Cooperation Exchange, Turkish-Slovak Forum or Bilateral Trade Summit, all of which took place in 2013,

- direct searching and screening of prospective partners abroad,

- providing of contacts on representative bodies of the Slovak Republic in given markets.

The Slovak Sourcing and Cooperation Portal provides an on-line database of the latest export opportunities, as well as the production cooperation offers. The aim of the Portal is to achieve more effective export promotion of Slovak products, intermediate the cooperation between Slovak and foreign companies and help the creation 
of Slovak-foreign joint ventures. The Portal cooperation offers are divided into four sections: subcontracting, joint ventures, investments and tenders. There is also the catalogue of the companies with the basic information about the business entities registered in the Portal (The Slovak Investment..., 2013).

Another tool for promotion of the partnerships, which was created in 2013, is the database of investment opportunities presented at the meetings with various foreign entities. The database contains information about the field of investment, the amount of capital needed and its planned usage and some general information about the investment opportunity (e.g., if the technology is patented, or the basic technical information).

\section{Enterprise Europe Network}

Enterprise Europe Network (EEN) is only one small piece in the process of helping small and medium-sized enterprises co-operate with each other. This network has been established by the European Commission in 2008 as the initiative of Competitiveness and Innovation Programme (CIP) (Enterprise Europe Network, 2013a).

The EEN connects business-supporting organisations from more than 50 countries ( $28 \mathrm{EU}$ countries and 26 non-EU members within Europe and abroad). The EEN has now close to 600 member organizations (also known as contact points) containing more than 6.000 experts (Enterprise Europe Network, 2013a). Members of the Network are usually the chambers of commerce, technology and innovation agencies, sector associations, regional development agencies, etc.

The mission of EEN is to help European SMEs to become more competitive, take benefit from the internal market, internationalize their businesses and increase their innovation capacity (European Commission, 2012). Experts working within the EEN help companies find international business partners, source new technologies and receive EU funding or financial support. EEN experts also advise companies on diverse issues such as intellectual property, internationalization, EU law and standards.

Increase of SMEs' competitiveness is one of the goals of the Operational programme research and innovations 2014 - 2020. One of the priorities set in order to achieve it is the development and implementation of new SME business models, notably in the field of internationalization. The foreign expansion ought to be focused on the non-EU countries. EEN is mentioned as one of the existing tools, which would fit into new, complex system of internationalization support (Ministry of Economy of the Slovak Republic, 2013).

The co-ordinator of EEN activities in Slovakia is Business and Innovation Centre Bratislava (BIC Bratislava spol. s r.o.). BIC Bratislava belongs to the network of the Business Innovation Centres (BICs) and Regional Advisory Innovation Centres which were co-ordinated by National Agency for Small and Medium Enterprises (Slovak Business Agency since March 1, 2014). These centres were established in 1993 to help Slovak small and medium enterprises with advisory and other services. Even though these centres formally exist nowadays, only a few of them fulfil their original role.

Other EEN partners in Slovakia include: SBA, Slovak Chamber of Commerce, Regional Advisory and Information Centre Prešov (RPIC Prešov), BIC Group and EurActiv. RPIC Prešov is located in eastern part of Slovakia (in the city of Prešov) and the rest of 
the partners are settled in Bratislava. Altogether, Slovakia has 6 EEN contact points. In Poland, there are 30 EEN contact points located in 19 cities.

There are several main EEN tools to enhance the co-operation between companies and to help them in their business. The following EEN services for companies and other relevant bodies are especially important for going international.

\section{Brokerage/Matchmaking events}

A matchmaking event is a quick and easy way to meet many potential co-operation partners in just one day. Many times, they take place at international fairs. People meet and greet in short bilateral meetings, which usually last 15, 20 or 30 minutes. (Enterprise Europe Network, 2013b). Usually, matchmaking events last one or two days.

The Network experienced some successful co-operation with Polish partners recently. The co-operation between Slovak EEN partner BIC Bratislava and Polish EEN partner Krakow Chamber of Commerce and Industry has been carried out. In October 2013, the brokerage event Furniture 2013 was organized in Bratislava (Slovakia) within the International Fair of Furniture, Housing and Office Interiors and Design (MODDOM). This event was aimed at companies functioning in the field of furniture production and distribution. As a result, three new potential co-operations between Slovak and Polish companies were launched (BIC Bratislava, 2013).

Slovak EEN partners are also helpful with the propagation of interesting co-operation events - like AutoEvent on Zawiercie (11th-13th of June 2013, Poland). Slovak EEN co-ordinator (BIC Bratislava) was helpful in contacting Slovak clients to take a part at this event, despite the fact that the organizer of this event (Polska Izba Motoryzacji - PIM) is not the member of the EEN yet. PIM was also co-organizer of AutoDay2013 event, which was organized in Bratislava as accompanying event to the automotive companies' mission from Poland to Slovakia in April 2013 (BIC Bratislava, 2013).

Every year several brokerage events are organized with the EEN support in Slovakia, including Engineering brokerage event, Slovak Matchmaking Fair and AutoDay.

\section{Seminars}

EEN partners organise seminars about various topics according to the current information needs of the companies, universities, researchers and other relevant entities (e.g., BIC Bratislava organized five Regional seminars about new EU programme Horizon 2020). SBA together with Slovak-Polish Chamber of Commerce organized a specific seminar "Doing business in Poland" which took place in Žilina, Slovakia in December 2013 (Enterprise Europe Network Slovensko, 2013).

\section{The Partnership opportunities database (POD)}

The Partnership Opportunities Database of Enterprise Europe Network is one of the world's largest business databases. It contains thousands (more than 23000 ) of profiles of companies which are looking for business, innovation or research partners. If the client finds a potential partner, EEN will provide him/her with its contact information. EEN partners are always informing the client about each expression of interest 
from foreign country. Subsequently, the client has the opportunity to contact the person interested to initiate co-operation (Enterprise Europe Network Brussels, 2013).

\section{Company missions}

A company mission is an organised visit to another country. A typical company mission within Europe lasts about one to two days and includes site visits, company and government agency presentations, and ample networking opportunities with local businesses (Enterprise Europe Network Yorkshire, 2013). Within the co-operation with Polish EEN branches, several company missions were carried out - e.g., company mission of Polish automotive companies to Slovakia or company mission of Polish furniture companies to Slovakia.

\section{Newsletters}

All EEN partners distribute regularly newsletter about EEN activities via e-mails and via social networks. The client can also find information online, not only on global Network webpage, but also on Slovak webpage of the Network.

\section{Direct contact}

One of the options how to introduce opportunities of EEN exploitation to potential EEN client is direct contacting of EEN contact point. In the period $2008-2012$, Slovak EEN partners organized nearly 180 seminars with more than 4500 participants, 66 matchmaking events and 21 company missions with 1500 participants. The Network team provided free consultation services for more than 5200 companies and visited more than 1000 companies to evaluate their business and technology opportunities. All these activities resulted in 66 international trade and technology partnerships.

Every member of EEN is obliged to publish the most inspirational success stories which explain how the EEN partner helped the specific entrepreneur. Two examples of these have been presented below to illustrate the EEN role in facilitating partnerships.

Polish company Orzeł SA is a seller of tyres, which previously sent used tyres to be burnt in cement factories. Nevertheless, the company wanted not only to fulfil recycling requirements, but also do it in a greener and efficient way. It therefore contacted EEN branch, which entered its request into the POD database. Austrian SME WIL AG, specialized in building tyre-recycling plants, answered the request and the two firms signed a deal, under which WIL will help to set up a recycling line in Orzeł factory and later, the Austrian company will sell the recycled parts from Poland to its clients in Europe. This co-operation also resulted in the creation of eight new jobs (Enterprise Europe Network, 2010).

The second case involves biotech company Sensara from the famous Spanish wine region La Rioja and Slovak company Biorealis, which specializes in measurement instruments for distillers, brewers and the wine industry. The two firms were matched via EEN contact points in Spain and Slovakia, respectively. The Spanish is testing two models of portable Biorealis analysers (Enterprise Europe Network, 2013c). 


\section{CONCLUSIONS}

The awareness of EEN tools is rather limited among the Slovak entrepreneurs, as only 88 company profiles from Slovakia are registered in the POD database (44 business offers, 6 business requests, 33 technology offers, and 5 technology requests). The Slovak Sourcing and Cooperation Portal registers 107 companies in its catalogue of business entities (the information are as of December 22, 2013). These rather low numbers of companies engaged in both of the databases might point to the lack of their interest in cooperation or the firms might as well be unaware of the possibilities provided by these cooperation tools.

The research of the Slovak-foreign joint ventures suggests that motives linked to the foreign expansion are among the most important for the joint venture establishment. The majority of the respondents are also satisfied with the joint venture performance and willing to participate in the company in long-term horizon. The findings suggest that the Slovak companies' cooperation with foreign enterprises can result in a successful business.

The research is limited by the number of companies which refused to participate in the survey or did not answer the request at all. Several joint ventures-turned-affiliates also could not participate because employees that might provide information about the motives for venture creation are no longer working in the company. Future research might focus on the state of the cooperation of the partners (does it continue, or was the joint venture dissolved or turned into affiliate) and the development of the joint ventures' export activities.

\section{REFERENCES}

BIC Bratislava. (2013). Autoday2013: International brokerage event in the field of Automotive Industry. Retrieved on December 16, 2013, from http://www.b2match.eu/autoday2013

BIC Bratislava. (2013). Furniture 2013. International Face2Face Networking event in the field of Furniture. Retrieved on December 17, 2013, from http://b2match.eu/furniture2013

Das, T.K., \& Teng, B.S. (2000). A Resource-Based Theory of Strategic Alliances. Retrieved on December 16, 2013, from http://aux.zicklin.baruch.cuny.edu/tkdas/publications/dasteng_jom00_resourcebasedtheory_31-61.pdf

Enterprise Europe Network. (2010). Success stories - Giving old tyres a new life. Retrieved on December 13, 2013, from http://een.ec.europa.eu/success-stories/giving-old-tyres-new-life

Enterprise Europe Network. (2011). Giving old tyres a new life. Retrieved on December 12, 2013, from http://een.ec.europa.eu/success-stories/giving-old-tyres-new-life

Enterprise Europe Network. (2013a). About - Our mission. Retrieved on December 16, 2013, from http://een.ec.europa.eu/about/mission

Enterprise Europe Network. (2013b). Services - Going international. Retrieved on December 11, 2013, from http://een.ec.europa.eu/services/going-international

Enterprise Europe Network. (2013c). Success stories - The wine analysers. Retrieved on December 10, 2013, from http://een.ec.europa.eu/success-stories/wine-analysers 
Enterprise Europe Network Brussels. (2013). The Partnership Opportunities Database of Enterprise Europe Network is now online! Retrieved on December 17, 2013, from http://www. brusselsnetwork.be/ going-international-m/1529-the-partnership-opportunities-database-ofenterprise-europe-network-is-now-online.html

Enterprise Europe Network Slovensko. (2013). Seminár - Podnikanie v Pol'sku. Retrieved on December 14, 2013, from

http://www.een.sk/?news/events/3799\&utm_source=Informa\%C4\%8Dn\%C3

\%A9+listy\&utm_campaign=7529006588-informa\%C4\%8Dn\%C3\%A9+listy_jun\&utm_medium= email\&utm_term=0_5db170a268-7529006588-12597669

Enterprise Europe Network Yorkshire. (2013). What are company missions? Retrieved on December 11, 2013, from http://www.eeyorkshire.com/yf/services/Company_Mission_Process.asp? Content $\mid \mathrm{D}=0178 \& \mathrm{BackTo}=0 \&$ savemsg $=\&$ CustomMessage $=$

European Commission. (2003). What is an SME? Retrieved on December 16, 2013, from http://ec. europa.eu/enterprise/policies/sme/facts-figures-analysis/sme-definition/index_en.htm\#top

European Commission. (2012). The Enterprise Europe Network Business and innovation support for European SMEs. Retrieved on December 16, 2013, from http://ec.europa.eu/enterprise/sectors/ tourism/files/tourism-euro-networkhidden/network_presentation_july_2012.pdf

Ferenčíková, S. (2001). Foreign direct investment as a factor of change: case of Slovakia. In D. Denison (Ed.), Teaching the Dinosaurs to Dance: Organizational Change in Transition Economies (pp. 445-481). Mahwah: Lawrence Earlbaum Publishers.

Ferenčíková, S. et al. (2013). Medzinárodná expanzia firiem: stratégie, partnerstvá a l'udské zdroje. Bratislava: lura Edition.

Ministry of Economy of the Slovak Republic. (2013). Stratégia vonkajšich ekonomických vztahov Slovenskej republiky na obdobie 2014-2020. Retrieved on December 15, 2013, from hsr.rokovania.sk/data/att/142708_subor.doc

Nowiński, W., \& Rialp, A. (2013). Drivers and strategies of international new ventures from a Central European transition economy. Journal of East European Management Studies, 17(2), 191-231.

Osarenkhoe, A. (2008). A study of the enablers of non-sequential internationalization process among small and medium-sized firms. Retrieved on December 14, 2013, from http://www.business-and-management.org/library/2008/3_2--1-20-Osarenkhoe.pdf

Oviatt, B. M., \& McDougall, P.P. (1994). Toward a theory of international new ventures. Journal of International Business Studies, 25(1), 45-64.

Teng, B. S., \& Das, T. K. (2008). Governance structure choice in strategic alliances. Retrieved on December 11, 2013, from http://aux.zicklin.baruch.cuny.edu/tkdas/publications/tengdas_md08_GovernanceStructureChoicelnSAs_725-742.pdf

The Slovak Investment and Trade Development Agency. (2013). About SARIO Portal Retrieved on December 20, 2013, from http://www.slovakiasourcing.com/?about-sario-portal 


\section{Authors}

\section{Mária Šášiková}

Bachelor of Business Activities in Foreign Trade (University of Economics in Bratislava, Slovakia); Master in International Trade (University of Economics in Bratislava, Slovakia); PhD student in International Business Management (University of Economics in Bratislava, Slovakia).

\section{Tatiana Hlušková}

Bachelor of Business Activities in Foreign Trade (University of Economics in Bratislava, Slovakia); Master in International Trade (University of Economics in Bratislava, Slovakia); PhD student in World Economy (University of Economics in Bratislava, Slovakia).

\section{Correspondence to:}

Ing. Mária Šášiková

University of Economics in Bratislava

Faculty of Commerce

Dolnozemská cesta 1, 85235 Bratislava, Slovakia

sasikova.m@gmail.com 